\title{
A glomus caroticum paragangliomája és ellátása
}

\author{
Gál Krisztián dr. ${ }^{1}$ - Apanisile Ifeoluwa dr. ${ }^{1}$ - Lázár István dr. ${ }^{2}$ \\ Blaskó Tünde $\mathrm{dr}^{3}{ }^{3}$ - Karosi Tamás dr. ${ }^{1}$ \\ Borsod-Abaúj-Zemplén Megyei Központi Kórház és Egyetemi Oktatókórház, \\ ${ }^{1}$ Fül-Orr-Gégészeti és Fej-Nyaksebészeti Osztály, ${ }^{2}$ Klinikai és Intervenciós Radiológiai Centrum, \\ ${ }^{3}$ Pathologiai Osztály, Miskolc
}

\begin{abstract}
Célunk egy 44 éves nőbeteg esetének bemutatása kapcsán rövid és átfogó képet adni a glomus caroticum paragangliomájáról, diagnosztikájáról és komplex ellátásáról. A glomus caroticum paragangliomája a glomus caroticumból kiinduló ritka, többnyire sporadikusan megjelenő, jóindulatú fej-nyaki daganat. A legtöbbször középkorú nőbetegek érintettek; a nyak egyik oldalán jelentkező, igen lassan növekvő, szemifix, fájdalmatlan nyaki duzzanatként jelentkezik. Diagnosztikájában a fizikális vizsgálaton túl (pulzáció, Fontaine-jel) az arany standard a CT-angiográfia. Hangsúlyozzuk, hogy a glomus caroticum paragangliomájának terápiájában alapvetô a preoperatív digitális szubsztrakciós angiográfia során elvégzett embolisatio, majd a tumor sebészi eltávolítása. Inoperabilitás és/vagy irreszekabilitás, illetve residualis tumor esetén a választandó terápia a sugárkezelés. A közleményben bemutatott beteget 2017 áprilisában kezeltük osztályunkon.
\end{abstract}

Orv Hetil. 2018; 159(36): 1487-1492.

Kulcsszavak: paraganglioma, glomus caroticum, digitális szubsztrakciós angiográfia

\section{Carotid body tumor and its treatment}

\section{$A$ case report}

Our goal was to report a 44-year-old woman with carotid body tumor, and to give a brief and comprehensive presentation about the disease and summarize its complex management. Carotid body tumor is a rare, mostly sporadic, benign head and neck mass originating from the glomus caroticum. It occurs mostly in middle-aged women as a slowly growing, semifix, painless neck mass. The diagnosis is based upon the physical examination (pulsatile mass, Fontaine-sign) and - as the gold standard - CT-angiography. It should be established that preoperative embolisation by digital substraction angiography plays a crucial role in the treatment of carotid body tumors that should be followed by surgical removal. In case of inoperable/irresecable and residual tumors, radiotherapy is the treatment option. The patient was treated in our department in April 2017.

Keywords: paraganglioma, carotid body, digital subtraction angiography

Gál K, Apanisile I, Lázár I, Blaskó T, Karosi T. [Carotid body tumor and its treatment. A case report]. Orv Hetil. 2018; 159(36): 1487-1492.

(Beérkezett: 2018. február 5.; elfogadva: 2018. március 12.)

\section{Rövidítések}

$\mathrm{ACC}=$ arteria carotis communis; $\mathrm{ACE}=$ arteria carotis externa; $\mathrm{ACI}=$ arteria carotis interna; CBT $=$ carotid body tumor, $\mathrm{a}$ glomus caroticum paragangliomája; $\mathrm{COPD}=$ (chronic obstructive pulmonary disease) krónikus obstruktív tüdőbetegség; $\mathrm{CT}=$ (computer tomography) számítógépes tomográfia;
DSA $=($ digital subtraction angiography $)$ digitális szubsztrakciós angiográfia; FNAC = (fine needle aspiration cytology) finomtú-aspirációs citológia; $\mathrm{MR}=$ mágneses rezonancia; $\mathrm{PVA}=$ polivinil-alkohol; VEGF = (vascular endothelial growth factor $)$ vascularis endothelialis növekedési faktor 

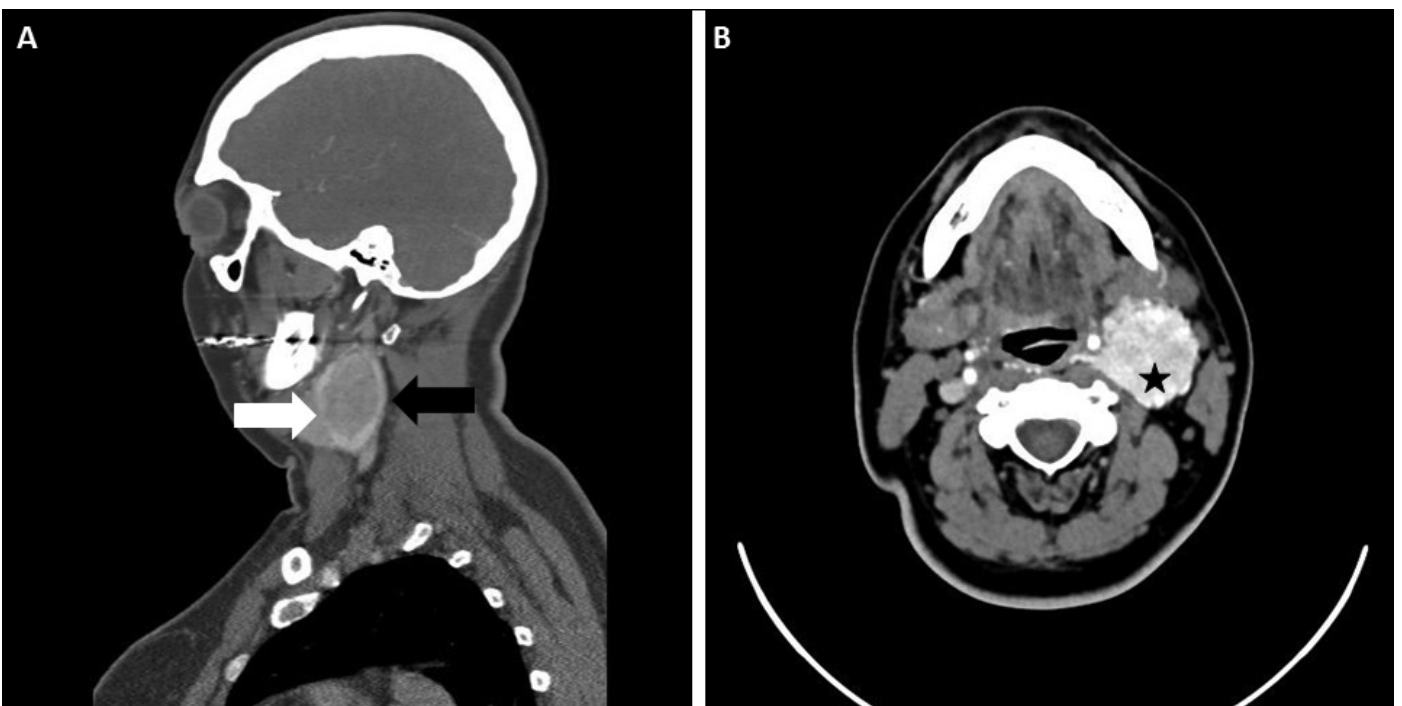

1. ábra

A) Kontrasztanyagos CT-felvétel paramedián sagittalis metszete. A tumor jól láthatóan diszlokálja az a. carotis externa (fehér nyíl) és az a. carotis interna (fekete nyíl) ágait - lírajel (lyre sign)

B) Kontrasztanyagos CT-felvétel horizontális metszete. A bal oldalon nagyméretű, kerekded, kontrasztanyagot intenzíven halmozó terime látható (csillag)

Egy 44 éves nóbeteg 8 éve progresszíven növekvő, bal oldali nyaki duzzanattal kereste fel járóbeteg-rendelésünket. Más intézetben történt FNAC-vizsgálatának leletét mutatta be, amely sejtszegénység miatt nem volt diagnosztikus értékü. A fizikális vizsgálat során a nyak bal oldalán, az ACC oszlásának magasságában $50 \times 40 \times$ 40 mm-es, a nagyerekkel együtt oldalirányban mozgó, de fel-le mozgatva immobilis (Fontaine-jel), rugalmas tapintatú, fájdalmatlan, pulzáló terimét észleltünk. Fülorr-gégészeti vizsgálattal a fej-nyak egyéb területén kóros eltérést a teriméhez kapcsolódóan, valamint attól függetlenül sem találtunk. Kóros belgyógyászati és neurológiai jelet nem láttunk. Az anamnézis és status alapján a glomus caroticum paragangliomája, CBT merült fel első diagnózisként.

A CT-angiográfos vizsgálat azonosított egy, az ACC oszlásában elhelyezkedő, azt ívelten diszlokáló, az érfalat infiltráló, $43 \times 34 \times 49$ mm-es, intenzíven kontrasztanyag-halmozást mutató terimét, igazolva a Shamblin szerinti III-as stádiumú (1. táblázat) CBT diagnózisát (1. ábra). A preoperatív digitális szubsztrakciós angiográfiát és egyben az ellátóerek embolisatióját intézményünk DSA-laborjában végezték el. Az angiográfos vizsgálat során az intracranialis anastomosisok nem telődtek, és az ACI felől sem látszott tumortelődés. Elsőként a bal arteria (a.) lingualist és az a. facialist coilokkal proximáli-

1. táblázat |Shamblin-stádiumok

\begin{tabular}{|c|}
\hline $\begin{array}{l}\text { I. A carotisok között elhelyezkedő tumorszövet } \\
\text { (az adventitiáról könnyen leválasztható) }\end{array}$ \\
\hline II. A carotisokat részben bennfoglaló tumorszövet \\
\hline $\begin{array}{l}\text { III. A carotisokat teljesen körülölelő tumorszövet } \\
\text { (ér feláldozására, rekonstrukciójára van szükség) }\end{array}$ \\
\hline
\end{tabular}

san lezárták, majd a bal carotis externa tumort ellátó afferenseibe 1 és 1/4 ampullányi, 710-1000 mikronos PVA (polivinil-alkohol)-szemcséket injektáltak (2. ábra). Az

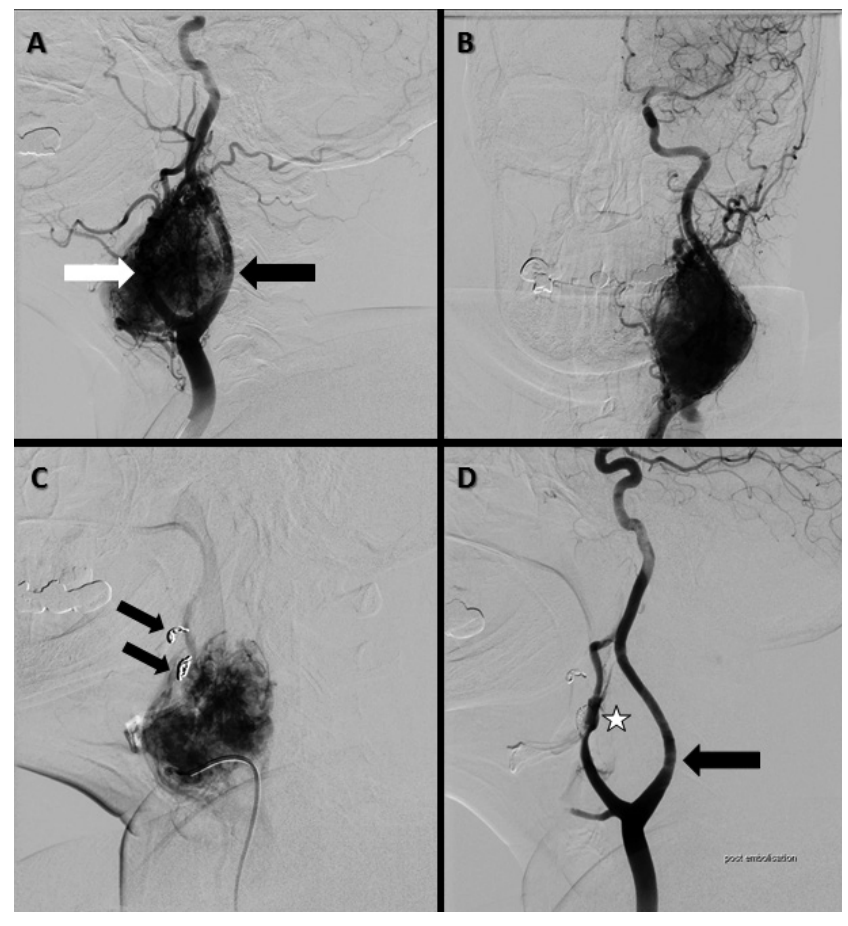

2. ábra

A glomus caroticum paragangliomájának DSA-felvételei A, B) Az a. carotis externa (fehér nyíl) és az a. carotis interna (fekete nyíl) ágait ívelten diszlokáló (lírajel) hipervaszkularizált tumorszövet látható. Fontos szempont, hogy a carotis ágai közt extra- és intracranialis anastomosisok nem telődtek, így elvégezhető az embolisatio

C) Az a. lingualis és facialis coilokkal lezárva (fekete nyilak); a tumor már kevésbé, de telődik

D) A polivinil-alkoholos embolisatio utáni DSA-felvétel. A tumor telődése megszúnt (csillag). Az a. carotis interna (nyíl) felől tumortelődés nincs 

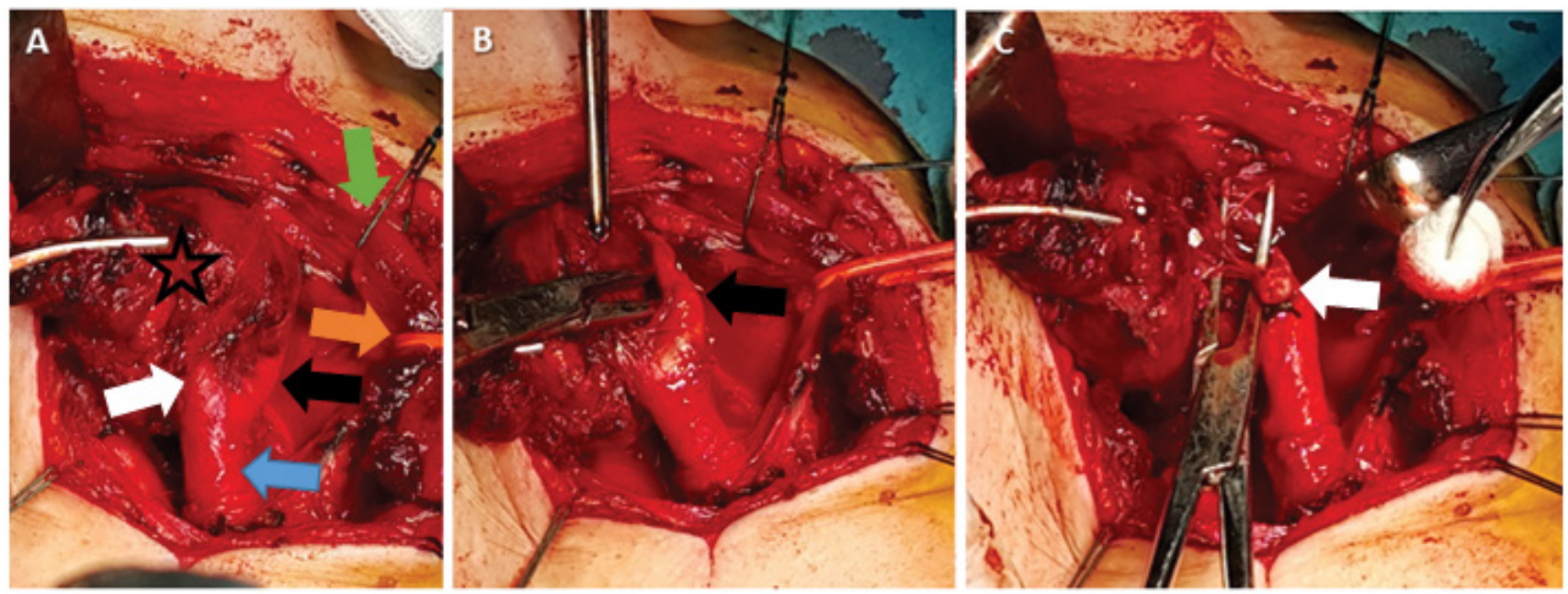

3. ábra

A) A mútéti terület, az a. carotis communis (kék nyíl) oszlása, attól cranialisan az a. carotis externát (fehér nyíl) és az a. carotis internát (fekete nyíl) körbeölelő, balról klammerbe fogott tumorszövet (csillag). Jobbra fent zöld varróanyaggal a musculus sternocleidomastoideust (zöld nyíl), attól lentebb narancssárga gumiszalaggal a vena jugularis internát tartjuk el (narancssárga nyíl)

B) A dissectorral eltartva látható, hogy a tumorszövet az a. carotis internáról lefejthető (fekete nyíl)

C) A tumorszövet az a. carotis externát oly mértékben infiltrálta, hogy attól elkülöníteni nem lehetett, az ér feláldozására kényszerültünk (fehér nyíl). Az ér feláldozásának korai vagy késői tünetei, szövődményei nem voltak
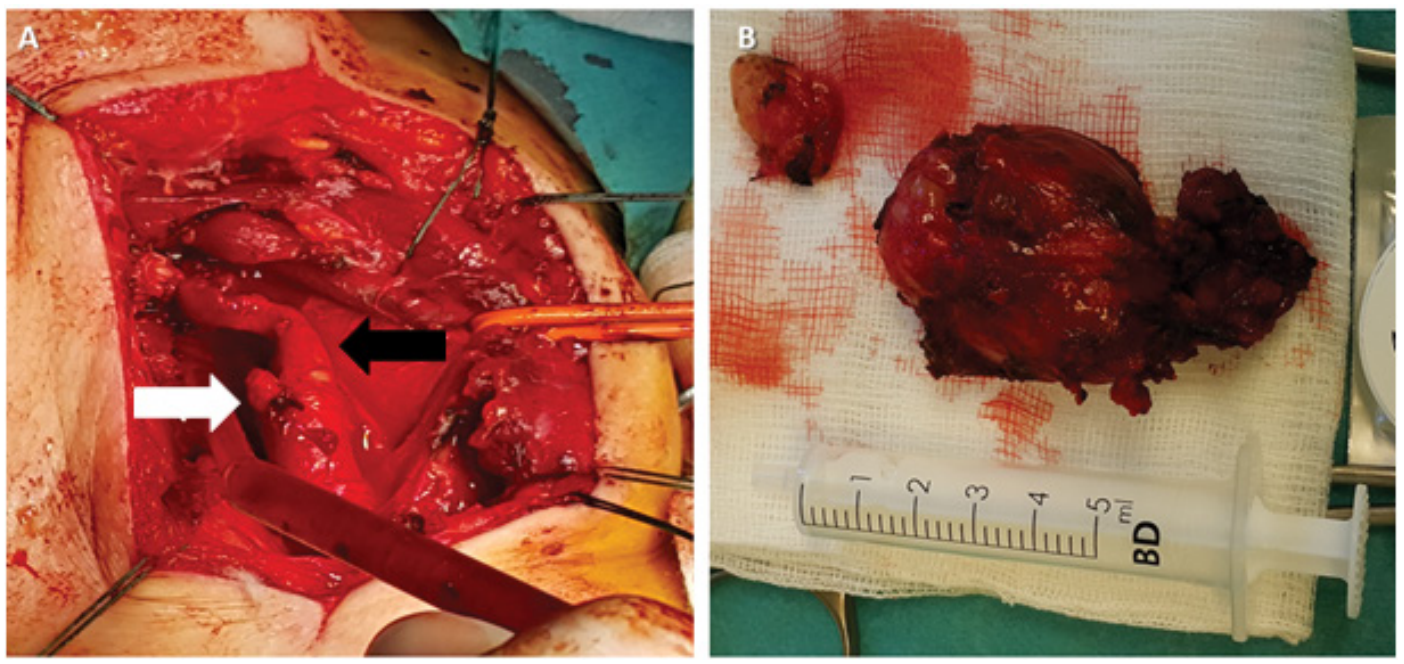

4. ábra

A) A mútéti terület a tumor eltávolítása után. Az a. carotis externa lekötve (fehér nyíl). Az a. carotis interna intakt (fekete nyíl) B) A körülbelül $5 \mathrm{~cm}$ legnagyobb átméröjú carotid body tumor specimen

embolisatio a tumor vascularis ágyát és annak keringését szubtotálisan csökkentette, szövődmény nem volt. A mütétet intratrachealis általános narkózisban végeztük. Lidokain-tonogén infiltrációja után a bal oldalon kb. 10 cm-es ívelt metszést vezettünk a musculus sternocleidomastoideus mentén, s a lágy részek preparálása, elkampózása után eljutottunk az ACC-oszlásig, ahol az ACEágat körülvevő, az ACI-ágat elfedő tumorszövetet láttunk (Shamblin III.). A vena jugularis internát, a musculus sternocleidomastoideust és a nervus (n.) vagust nem infiltrálta a tumor. A tumor felső széle felől megtaláltuk a coilozott afferens ereket, a coilt eltávolítottuk, majd lekötöttük az artériákat. Inferior irányból az ACC, az ACC oszlása, majd a tumor környezetének kipreparálása után láthatóvá vált, hogy a tumor olyan mértékben infiltrálta az ACE-t, hogy az nem volt megtartható, így a tumorral együtt, az ACC-oszlástól distalisan 1 cm-re lekötöttük és eltávolítottuk (3. és 4. ábra). A tumor szövettani metszetei a 5 . ábrán láthatók. A mütéti videó a 6 . ábra magyarázata után szereplő YouTube ${ }^{\mathrm{TM}}$ linken található. A posztoperatív szakban szövődményt nem észleltünk, a beteg az ápolás 5 napja alatt egyedül a a nyaki seb területén jelentkező fokozódó fájdalomra panaszkodott, melyet $50 \mathrm{mg}$ diklofenák és $50 \mathrm{mg}$ tramadol szükség szerinti, váltott használata mellett uralni tudtunk. Sebgyógyulása zavartalanul zajlott, 10 nappal később a varratok eltávolításakor elsődlegesen gyógyult heget láttunk. A beteg továbbra is fájdalomra panaszkodott, így otthonában tramadol $50 \mathrm{mg}$ tabletta szükség szerinti szedését javasoltuk. Páciensünk jelenleg panaszmentes, és fél évvel a beavatkozás után végzett $M R$-angiográfos vizsgálaton recidíva nem volt látható (6. ábra). 

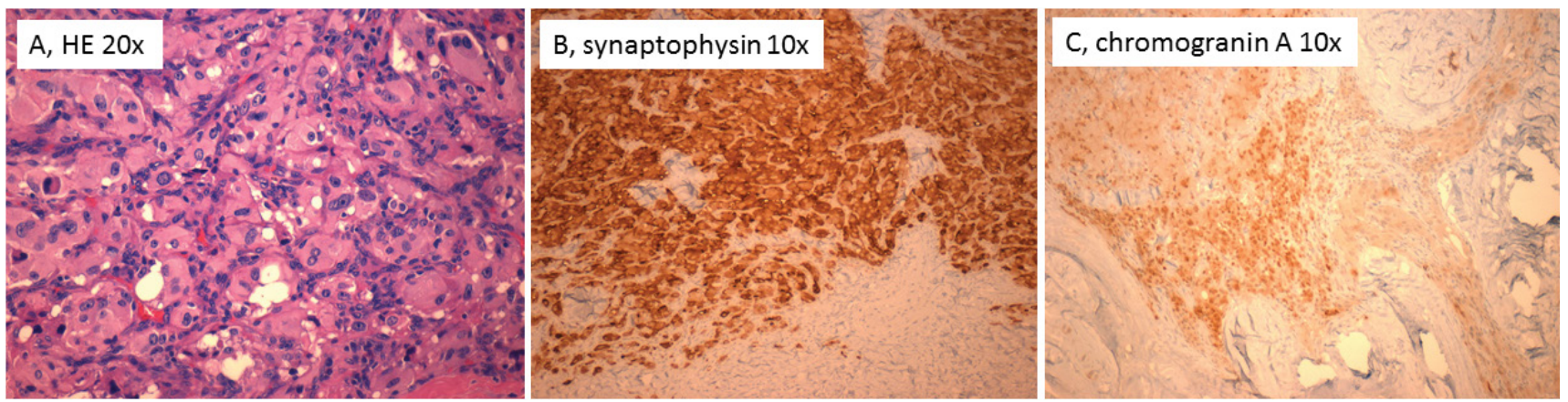

5. ábra

A) A glomus caroticum paragangliomájának hematoxilin-eozin metszete 20x-os nagyításban. A kötőszövetes állományban bőséges eosinophil citoplazmával bíró, fészkes megjelenést mutató daganatsejt-proliferáció. A magok mérsékelt magpolimorfiát mutatnak, ovoidok, rögös magkromatinszerkezettel bírnak, és nucleolusok láthatók

B) A glomus caroticum paragangliomájának immunfluoreszcens, szinaptofizinmetszete 10×-es nagyításban

C) A glomus caroticum paragangliomájának immunfluoreszcens, kromogranin-A-metszete 10×-es nagyításban
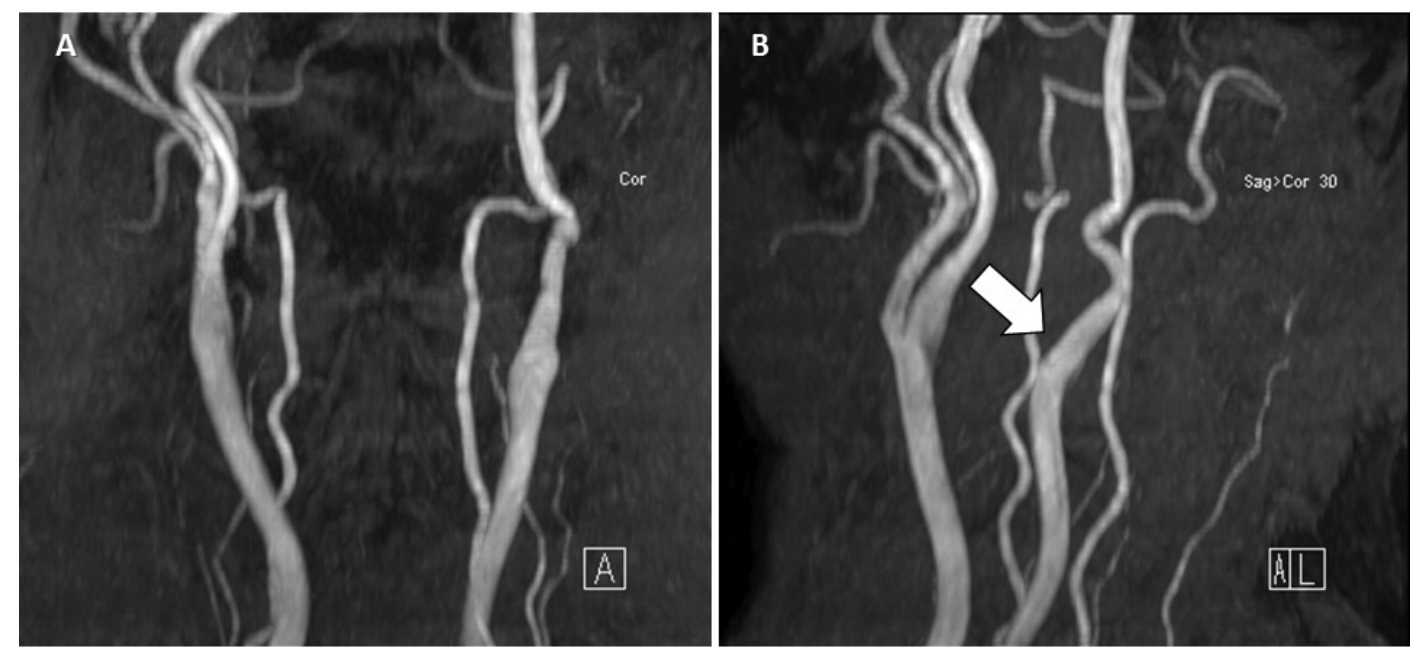

6. ábra

A, B) Posztoperatív, fél évvel a mútét után készült MR-angiográfos felvételek. Recidíva nincs, a bal oldali carotis externa reszekált (fehér nyíl). Mútéti videó: https://youtu.be/Bpr4rlWgktY

\section{A glomus caroticum paragangliomája, carotid body tumor}

\section{Áttekintés}

A paragangliomák ritka neuroendokrin tumorok. Kiindulási pontjaik az extraadrenalis autonóm paraganglionok, melyek fóként neuroendokrin sejtekből álló, az embrionális velőcsőből kifejlődő, katecholaminszekretáló kis szervek.

A fej-nyak paragangliomái paraszimpatikus eredetűek, a n. glossopharyngeus és a n. vagus lefutását követik. A glomus caroticum az ACC oszlásában posteromedialisan elhelyezkedő kemoreceptor sejtcsoport, fiziológiásan 3-5 mm átmérőjü, tömege $15 \mathrm{mg}$ alatt van [1]. Vérellátását az ACE ágaiból, típusosan az a. pharyngea ascendensből és az a. occipitalisból kapja; beidegzéséért a n. glossopharyngeusból (IX.) a foramen jugulare szintje alatt kb. 1,5 cm-rel eredő Hering-féle ideg felel [2]. A vérplazma összetételének „monitorozásával” és ehhez kapcsolt katecholaminszekréciójával fontos szerepe van a testünk fluktuáló oxigén-, szén-dioxid- és pH-szintjéhez való gyors adaptációjában. Az ezekból a sejtekből kiinduló jóindulatú daganat a CBT. A fej-nyak paragangliomáinak incidenciája $\mathrm{l}-2 / 100000$, a CBT-k a fej-nyak paragangliomáinak $65 \%$-át adják [3]. Három formáját írták le, familiáris, sporadikus, hyperplasiás. A leggyakrabban, az esetek $85 \%$-ában sporadikus megjelenésú. A hyperplasiás forma krónikus hypoxiás állapotú betegekben gyakori, az 1500 méter tengerszint feletti magasságban élők (például Új-Mexikó és Colorado [Amerikai Egyesült Államok], Peru), valamint COPD-s vagy cianózissal járó szívelégtelenségben szenvedők betegsége [4].

A CBT a középkorúak betegsége, az átlagéletkor 45 év. (2) 10-50\%-ban örökölt a betegség, ebben az esetben az átlagéletkor alacsonyabb, 20-40 év között van [5].

A CBT-k 5\%-a kétoldali és 5-10\%-uk malignus; az öröklött formában a kétoldaliság és a malignitás aránya magasabb [6].

Etiológiájában rizikófaktor a krónikus hypoxia és a genetikai prediszpozíció. Genetikai prediszpozícióról az 
öröklött formában beszélhetünk. Heterogén entitás: ez idáig 4 gént sikerült azonosítani, melyek közül 3 a SzentGyörgyi-Krebs-ciklus szukcinát-dehidrogenáz enzimkomplex alrészeit kódolja. A negyedik gén terméke azonosítatlan [7]. A szukcinát-dehidrogenáz hibás müködésének következtében a vascularis növekedési faktor (VEGF) és az intracelluláris molekuláris hypoxia mediátorok szintje növekszik, így okozva hyperplasiát, angiogenezist és neoplasiát a glomusban [3].

A krónikus hypoxia - például hegyi településeken élőkben, cianózissal járó szívbetegekben, COPD-s betegekben - túlterheli a glomus caroticum sejtjeit, így okozva hypetrophiát, hyperplasiát, neoplasiát; ennek mechanizmusa mind ez idáig ismeretlen [7].

A CBT esetenként nem paragangliomákkal asszociált daganatszindrómák része is lehet, például MEN II. szindróma, von Hippel-Lindau-szindróma, I-es típusú neurofibromatosis.

A CBT a legtöbbször az elülső nyaki háromszögben okoz progresszíven növekvő duzzanatot. Jansen és mtsai képalkotó vizsgálati megfigyelése alapján átlagban 0,83 mm-t nó évente, a méretét 7,13 év alatt duplázza meg (Td) [8].

A fizikális vizsgálat során típusos a Fontaine-jel: a terime horizontális irányban mobilis, de vertikálisan fixált az ACC-oszláshoz való fixációja miatt. A terime felett gyakran zörej hallható, tapintásra pedig a vér áramlása érezhető; e tünetek hiánya azonban nem zárja ki a CBT lehetôségét.

Az esetek 10\%-ában agyidegtünetek is kísérik a CBT-t: bénulhat a n. hypoglossus (XII.), a n. glossopharyngeus (IX.), a n. laryngeus recurrens (X.), a n. accessorius (XI.) vagy a szimpatikus idegfonat. Ennek megfelelően a CBT-t kísérheti fájdalom, rekedtség, nyelészavar, a nyelv bénulása, Horner-szindróma vagy a vállöv azonos oldali izomgyengesége, aszimmetriája [9]. Funkcionáló, katecholaminszekretáló CBT esetén a tünetek hasonlóak a pheochromocytomás betegekéihez: izzadás, paroxismalis hypertensio, palpitatioérzés.

Funkcionáló CBT-re utaló tünetek esetén a vizelet katecholaminszintjeinek vizsgálata diagnosztikus értékü.

Képalkotó vizsgálatként ultrahang (Duplex), CT, CTangiográfia, MR és MR-angiográfia használatos. A betegségben alapvető diagnosztikai értékkel bíró, Tl- és T2-súlyozott MR-felvételen karakterisztikus a terime hypervascularitasa miatt látható „salt and pepper” jel. Az erek helye a flow void jelenségből adódóan sötét, jelmentes, ez a „pepper/bors” jel. A „salt/só” az intratumoralis lassú áramlás és a pontszerü vérzések hiperintenzív jele (7. ábra) [10]. Szintén jellemző radiológiai kép a diszlokált ACE- és ACI-ágak és a közrefogott tumorszövet adta lírajel (lyre sign, 1. ábra). Az ellátóerek és a Shamblin-féle stadizálás (1. táblázat) szempontjából a CT-angiográfia bír a legtöbb információval, így a mútét tervezésének arany standardja [11]. A szerzők kiemelik, hogy az embolisatio önmagában nem elégséges, kizárólag preoperatív beavatkozás, így azt a terápiában sebészi

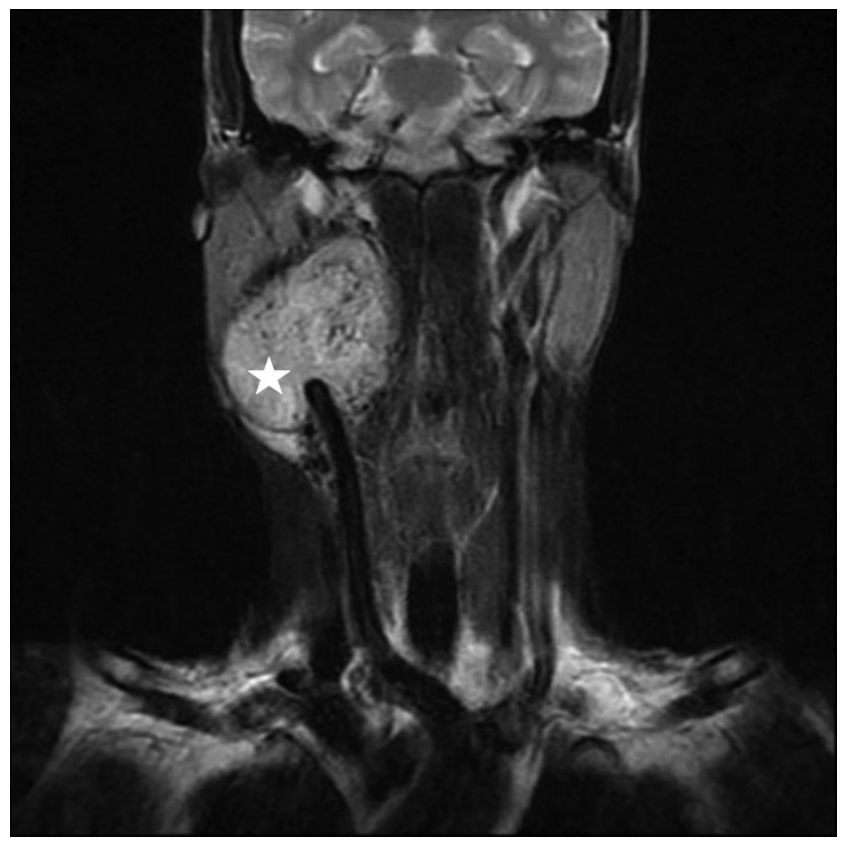

7. ábra

A „salt and pepper” jel T2-súlyozott MR-felvételen (fehér csillag) (dr. Arthur Daire, Radiopaedia.org, rID: 30208)

eltávolításnak kell követnie. A CBT szövetének és az ellátóereknek a múvi embolisatióját követő gyors rekanalizáció miatt a mútéti eltávolítás $48-72$ órán belül elvégzendő. A nyaki biopszia CBT gyanúja esetén kontraindikált, finomtû́-aspirációs citológiai vizsgálat csak a diagnosztikai vizsgálatok ellentmondásossága esetén jöhet szóba [12].

A mútéti eltávolítás általános érvényü megfontolásaiban utalunk a fent leírt esetre és a 3. és 4. ábra magyarázataira.

Intraoperatív szövődményként a vérzés elsődleges rizikóval bír, mely megfelelő mütéti technikával és a preoperatív embolisatióval minimalizálható. Az idegek közül a n. laryngeus superior sérülése a leggyakoribb, következményeként a beteg változó mértékű és gyakoriságú aspirációtól és hangjának megváltozásától szenved majd. A n. vagus (X.) sérülése a hangszalag bénulásán keresztül rekedtséget, aspirációt okoz. A n. hypoglossus (XII.) sérülése beszéd- és nyelészavart idéz elő. A n. accessorius (XI.) sérülése a váll fájdalmával és gyengeségével jár, a következménye jelentős mozgáskorlátozottság is lehet.

A beteg mütét utáni megfigyelése posztoperatív őrzőben javasolt. Komplikációként a vérzés és a késői stroke lehetőségét kell szem előtt tartani. Fontos a megfelelő fájdalomcsillapítás és a szoros obszerváció. A beteg utánkövetésére a fizikális vizsgálat mellett az MR-képalkotás javasolt.

A CBT-ben szenvedő beteg ellátása minden esetben és egészében olyan intézetben javasolt, ahol megfelelő tapasztalattal és felszereltséggel rendelkező fej-nyak sebészeti centrum mellett a radiológiai háttér, a diagnosztikus és a terápiás DSA is elérhető. 
Inoperábilis beteg és/vagy irreszekábilis CBT esetén radioterápiás kezelés javasolt. Residualis tumor esetén is a sugárkezelés a választandó terápia. Többgócú paraganglioma vagy agyi érpatológiával komplikált glomustumor esetén az endovascularis, intervenciós radiológiai beavatkozás és az azt követő sugárkezelés javasolt [13].

Anyagi támogatás: A közlemény megírása, illetve a kapcsolódó kutatómunka anyagi támogatásban nem részesült.

Szerzői munkamegosztás: G. K.: Operáló asszisztens, a cikk szövegének megírása és szerkesztése. A. I.: Fotódokumentáció. L. I.: DSA elvégzése. B. T.: Szövettani leletezés. K. T.: Témavezető, operatőr. A kézirat végleges változatát valamennyi szerző elolvasta és jóváhagyta.

Érdekeltségek: A szerzőknek nincsenek érdekeltségeik.

\section{Irodalom}

[1] Lack EE. Anatomy and physiology of peripheral arterial chemoreceptors. In: Pathology of adrenal and extra-adrenal paraganglia. W.B. Saunders, Philadelphia, PA, 1994; pp. 1-14

[2] Day TA, Joe JK. Primary neoplasms of the neck. In: Cummings CW. (ed.) Cummings otolaryngology - head and neck surgery. 4th edn. Elsevier-Mosby, St. Louis, MO, 2005; p. 113.

[3] Sevilla García MA, Llorente Pendás JL, Rodrigo Tapia JP, et al. Head and neck paragangliomas: revision of 89 cases in 73 patients. Acta Otorrinolaringol Esp. 2007; 58: 94-100.
[4] Sajid MS, Hamilton G, Baker DM. A multicenter review of carotid body tumour management. Eur J Vasc Endovasc Surg. 2007; 34: 127-130.

[5] Jani P, Qureshi AA, Verma S, et al. Familial carotid body tumours: is there a role for genetic screening? J Laryngol Otol. 2008; 122: 978-982.

[6] Netterville JL, Reilly KM, Robertson D, et al. Carotid body tumors: a review of 30 patients with 46 tumors. Laryngoscope 1995; 105: 114-126.

[7] Baysal BE, Myers EN. Etiopathogenesis and clinical presentation of carotid body tumors. Microsc Res Tech. 2002; 59: 256-261.

[8] Jansen JC, van den Berg R, Kuiper A, et al. Estimation of growth rate in patients with head and neck paragangliomas influences the treatment proposal. Cancer 2000; 88: 2811-2816.

[9] Işik AC, Imamoğlu M, Erem C, et al. Paragangliomas of the head and neck. Med Princ Pract. 2007; 16: 209-214.

[10] Chavhan GB, Shroff MM. Twenty classic signs in neuroradiology: A pictorial essay. Indian J Radiol Imaging 2009; 19: 135145.

[11] Arya S, Rao V, Juvekar S, et al. Carotid body tumors: objective criteria to predict the Shamblin group on MR imaging. Am J Neuroradiol. 2008; 29: 1349-1354.

[12] Knight TT Jr, Gonzalez JA, Rary JM, et al. Current concepts for the surgical management of carotid body tumor. Am J Surg. 2006; 191: 104-110.

[13] Oláh Cs, Czabajszki M, Lázár I. Endovascular treatment of complex vascular pathology in neck and brain region. Case report. [Komplex nyaki és agyi érpatológia endovascularis kezelése.] Orv Hetil. 2017; 158: 706-710. [Hungarian]

(Gál Krisztián dr., Miskolc, Szentpéteri kapu 72-76., 3526 e-mail: drgalkrisztian@gmail.com)

\section{Az Orvosi Hetilap 2018, 159, 1292. oldalán (31. szám) megjelent OH-Kvízre két helyes megfejtés érkezett.}

A beküldők: Dr. Bíró László (Budapest) és Dr. Somogyi Erzsébet (Miskolc).

A nyerteseknek szívből gratulálunk.

A nyereményüket - egy, az Akadémiai Kiadó webáruházában

kedvezményes vásárlásra jogosító kupont - e-mailen küldjük el. 